\author{
Slavcho Rakovsky ${ }^{1}$ and Gennady Zaikov ${ }^{2}$
}

\title{
APPLICATION OF OZONE IN MEDICINE
}

\author{
${ }^{1}$ Institute of Catalysis, Bulgarian Academy of Sciences, 1113 Sofia \\ ${ }^{2}$ Institute of Biochemical Physics, 117334 M oscow, Russia; chembio@sky.chph.ras.ru
}

Received: J uly 08, 2008

(C) Rakovsky S., Zaikov G., 2009

\begin{abstract}
This review deals with the application of ozone in medicine, its effects on the human organism and its use as a therapeutic approach and sterilizing agent. A particular attention is paid to the therapeutic properties, therapeutic dosage and scope of application. Some mechanisms of the ozone effect at exposure on different organs and systems in human body are also considered. Ozone toxicity is reviewed. The ozone use as a sterilizing agent in the pharmaceutical industry and cosmetics, as well as in the food processing industry is discussed.
\end{abstract}

Keywords: ozone, medicine.

\section{Introduction}

Upon exposure of living organisms to ozone, depending on doses, the different vital systems can be suppressed or stimulated to a certain extent.

For the first time in 1898 already Binz [1] showed interest to the effect of ozone on blood and plasma and found that ozone exhibits a somnolent effect. Brinkmsen and Lambert [2] proved that ozone inactivates the cell enzymes and decreases the oxygen exchange between blood and tissues.

A thorough investigation of the ozone effect on the human organism should allow to extend the range of its application in medicine. The operation mechanism of ozone at small (therapeutic) concentrations, up to $100 \mu \mathrm{g} / \mathrm{m}^{3}$, in the human cell has already been studied. Ozone enhances the cell membrane resistance to damaging effects. Human blood, treated with ozone, is able to keep erythrocyte membranes intact from 5 to 15 days. The method for preparation of nonhemolyzed plasma has been developed which facilitates laboratory diagnostic investigations and preserves blood, without inducing hemolysis [3]. In vivo and in vitro experiments have shown that ozone stimulates erythrocytes gas-transportation function which provides a continuous optimum tissue oxygenation. Besides, ozone strengthens leukocytes antibacterial function, the high activity of the mieloperoxidase enzyme system being preserved for 15 days. Ozone could also have found wide application in disinfection of biological materials, blood in particular. Encouraging results of HIV inactivation by means of ozonolysis have been reported [4-10]. Blood, plasma, infected with retrovirus HIV, which transcriptase (RT) activity was $1.4 \cdot 10^{5} \mathrm{cmp} / \mathrm{ml}$ were separated into three fractions (A, B, C). Fraction A and fraction B (after cryoprecipitation) were exposed to ozone, $12 \mu \mathrm{g} / \mathrm{ml}$, at $273 \mathrm{~K}$ for $30 \mathrm{~min}$. Fraction C was not treated with ozone. Subsequently, after 13 days of incubation, the following changes in RT activity were observed: fraction $A=130000$, $\mathrm{B}=0, \mathrm{C}=175000$. In acute massive blood losses the adaptive potentialities of the human organism increase if small doses of ozone are inhaled. Besides, the operating strength of the intracellular mechanism of hemoglobin antioxidative resistance is enhanced, as deduced from superoxide dismutase activation in erythrocytes. Prophylaxis in hemorrhages by means of ozone inhalation is due to the activation of biological processes which provide erythrocytes gas-transportation function. The application of ozone in medicine opens prospects to invent means for correcting the respiratory system by changing the molecular regulation mechanism of hemoglobin affinity to oxygen under various hypoxic conditions.

Methods can be developed to preserve blood cell vitality and dynamic activity during conservation and transfusion. There is a growing interest in looking for techniques for ozone use for cardiovascular diseases. Combined effects and hyperbaric oxygenation under conditions related to hypoxia have also been studied.

The ability of ozone to oxidize toxic products, formed under various pathological conditions, has attracted clinicians' attention. Ozone either directly oxidizes double bonds (in saturated compounds) or, by activating free radical processes, initiates a danger of enhancing the spontaneous process of lipid peroxide oxidation. Kontorshticova and Andreeva [11] studied the lipid and protein spectra of blood plasma exposed to ozone. Blood, taken from a dog 15 min after suffering from hemorrhagic shock, was exposed for 5 min to oxygen-ozone mixture at the rate of $11 / \mathrm{min}$ and ozone concentration $0.048 \mathrm{mg} / \mathrm{l}$. The total protein content and separate protein fractions 
were analyzed. The fatty acids content was determined by gas chromatography (GC). The protein and lipid spectra reflect processes which take place in hypoxia and subsequent oxygenation in the organism of test animals. These are: i) elimination of lipid depots of nonesterified fatty acids; ii) nonoxidized or partially oxidized products of lipid and protein nature; iii) blood saturation with oxygen and activation of oxygenation processes. An increase in $\alpha_{2}$-globulin content zeruloplasmin and haptoglobin, which possess antioxidative properties, is observed in the protein spectrum. The content of fatty acids decreases by about two fold. The total protein and $\beta_{2}$-globulin concentrations also decrease. These changes are consistent with a direct effect of ozone on peptide bonds in proteins and on double bonds in unsaturated fatty acids. Fairly high doses of ozone can be employed to saturate blood with oxygen and deactivate nonoxidized and partially oxidized products. Therapeutic doses of ozone, $0.048 \mathrm{mg} / \mathrm{l}$, are applied to correct pulmonary insufficiency in postreanimation periods.

High concentrations of ozone, $0.2 \mathrm{mg} / \mathrm{l}$, can be used under model pathological conditions which allow to study morphological changes in pulmonary tissue. The effect of ozone upon varying the mode of administration in the organism has also been investigated [12].

An isotonic $\mathrm{NaCl}$ solution saturated with ozone was injected intracutaneously or a saturated aqueous solution was administered orally to rabbits. In animals, injected with ozonized water, the red blood cells level remained stable in the course of experiment (10 days). An increase in leucocyte level (twice) was observed at the expense of monocytes. Changes of granulocytes were not pronounced. The functional activity of neutrophilic cells, evaluated by phagocytosis activity, increases in 1.5 times. On intracutaneous administration of ozonized isotonic $\mathrm{NaCl}$ solution, the leucocyte level was diminished after the first hour, enhanced after the third hour and remained high by the end of the experiment with respect to the initial level. By comparing these two methods, it was established that the toxic effect was more pronounced with the intracutaneous administration than the oral one. Thus, for example, the activity of the process of lipid peroxide oxidation, evaluated through malonic dialdehyde determination in erythrocytes, increases in 3 times upon intracutaneous injection and did not change after oral administration. At exposure of blood from healthy donors aged $25-35$ to $3 \mathrm{mg} / \mathrm{l}$ ozone the activity of the aspargataminotranspherase increased whereas that of lactic dehydrogenase attained a maximum concentration and then fell down to the initial one.

Ozone therapy, being an effective means to treat a number of diseases, attracts the attention of practising clinicians, dermatologists in particular [13]. Attempts have been made to treat various dermatoses: psoriasis, herpes, lichen, microbial eczemas, acne vulgarize etc. [14]. The obtained results were positive. The effect of ozone on human has focused scientists' attention for more than two decades. The oxidative effect of ozone on cells, especially tumor cells, is of particular interest [15-17]. Cells from alveolar adenocarcinomas, breast adenocarcinomas and uterine carcinosarcoma and normal cells from lung diploid fibroblast as a reference were incubated in a special chamber. They were exposed to ozone ( 0.3 to $0.7 \mathrm{ppm})$ for 8 days. The number of cells was determined every $48 \mathrm{~h}$. Ozone levels from 0.3 to $0.5 \mathrm{ppm}$ inhibited the accumulation of tumor cells by $40-60 \%$ and did not affect normal cells. The inhibition was $90 \%$ at the concentration of $0.8 \mathrm{ppm}$. Many viruses are sensitive to ozone, for example vesicular stomatitis, encefalomyocarditis, poliovirus type 2 and 3, coxsacknevirus, echovirus, and adenoviruses [18-20]. The authors have studied the inactivation of rotaviruses HRV type 2 from persons and SA-11 from apes at various exposures of ozone $(0.05$, 0.1 and $0.2 \mathrm{mg} / \mathrm{l})$ at $277 \mathrm{~K}$. HRV was considerably more sensitive to ozone than S-11. In this connection ozone might find therapeutic application in oncology [21].

\section{Basic Clinical Applications of Ozone Therapy}

As a therapeutic means the so-called medical ozone is employed in concentrations from 0.05 to $5 \mathrm{vol} \%$.

Types of application and adequate range of therapeutic doses of medical ozone-oxygen mixtures. Colonic insufflation and external gas treatment in a closed system. Intravenous, intramuscular and subcutaneous administration. Blood treatment. Ozonized water production. Stimulating treatment. Circulatory. Wound cleansing and disinfection. Ozone therapy is successfully applied in a wide variety of diseases as it is shown in Table 1 .

\subsection{Intraarterial Application}

As a rule, the ozone-oxygen mixture is employed in cases of arterial circulatory disturbances. This method was first described by Dr. Lacoste in 1951 and since then has attracted the attention of many scientists. O.Rokitansky [22] was the first who made a statistical evaluation, according to which four out of ten patents with arterial-metabolic circulatory disturbances treated with ozone did not need operation [23, 24].

\subsection{Rectal Application}

This method (called ozone enema) was reported in 1935 and its successful application has been proved in cases of mucous colitis and fistulae. It was established that the oxygen content in blood increases [25, 26]. 


\begin{tabular}{|l|l|}
\hline \multicolumn{1}{|c|}{ Disease } & \multicolumn{1}{c|}{ Medical field } \\
\hline Abscess & Surgery, dermatology \\
\hline Acne & Dermatology \\
\hline Allergies & General medicine, dermatology, allergology \\
\hline Anal fissure & Dermatology, proctolo \\
\hline Arterial circulatory disturbances & Surgery, vascular surgery \\
\hline Cerebral sclerosis & Gerontology, internal medicine, neurology \\
\hline Cirrhosis of the liver & Internal medicine \\
\hline Climacterium/menopause & Gynecology \\
\hline Constipation & Internal medicine \\
\hline Cystitis & Urology \\
\hline Decubitus (ulcers) & Surgery, gerontology, dermatology \\
\hline Fistulare & Proctology, dermatology, urology, gynecology \\
\hline Furunculosis & Dermatology \\
\hline Gangrene & Surgery \\
\hline Hepatitis & General medicine, internal medicine \\
\hline Herpes (AIDS) & Dermatology, internal medicine \\
\hline Hypercholesterolaemia & Internal medicine \\
\hline Mucous colitis & Proctology, gastroenterology \\
\hline Mycosis/fungus infections & General medicine, dermatology \\
\hline Oncological additives & Oncology and relevant fields \\
\hline Osteomyelitis & Surgery \\
\hline Parkinson's disease & Neurology \\
\hline Polyarthritis & Internal medicine, neurology \\
\hline Radiation scars (following irradiation treatment) & Radiology, dermatology \\
\hline Raynaud's disease & Surgery, vascular surgery \\
\hline Spondylitis & Orthopedics, surgery \\
\hline Stomatitis & Odontology, dentistry \\
\hline Sudeck's disease & Surgery, orthopedics \\
\hline Thromboflebitis & Internal medicine, dermatology \\
\hline Ulcus cruris & Dermatology \\
\hline Virus infections & AIDS, various special fields \\
\hline Wound healing disturbaces & Surgery \\
\hline & \\
\hline
\end{tabular}

\subsection{Ozone Aqueous Solution}

Ozone disinfectant and sterilizing properties were used to freshen water in Germany at Wiesbaden as far back as in 1902. On this basis in 1934 the dentists started utilizing ozonized water for inflammatory processes. This was reported at the Sixth World Congress on Ozone held in Washington [27]. The following properties of ozone are used in this case: (i) disinfectant and sterilizing effect; (ii) haemostatic effect, especially in cases of running hemorrhages; (iii) accelerated wound healing, improved oxygen local supply and support of metabolic processes $[28,29]$. Ozonized water, in the form of spray or stream, is used for the antrum in the following cases: gingivitis, paradontosis, white-gum, stomatitis. Preference is given to the spray mode, particular in cases of caries for cleaning and disinfection as well as for injuries and bleedings in the antrum. It is applied in cleaning nerve canals and pulpa tissue, in cases of painful gingivitis and stomatitis. Ozonized water has also found wide application in orthopedy: artificial denture and crown cleaning prior to fixing, stopping of hemorrhages during fixing.

\subsection{Intracutaneous Ozone Application}

Ozone has shown an antalgic effect, this property being used through injections in cases of pains of the spinal column. One should be careful with sensitive patients, since the initial pain of the injection is considerable. The analgesic effect of ozone has been tested by Pribluda [30] who injected intracutaneously $30-50 \mathrm{~cm}^{3}$ of ozone in the lumber and sciatic region to relieve pain. 


\subsection{Ozone Gas Application}

Wolff [31] reported that as early as 1915 ozone was provided for local gas treatment in cases of fistulae, decubitus (ulcers), ulcus cruries, osteomyelitis as well as badly healing wounds. For that purpose plastic bags filled with gas mixture were employed. This therapy became particularly useful for inaccessible ulcers, fistulae and damage from X-radiation. Payr [32] applied subcutaneous injection of ozone gas in cases of venous circulatory disturbances and varicosis. For the same cases he also used intravenous injection. He also reported that Dr. Fisch had tested this method on himself without side effects.

The intraarterial application of ozone therapy is promising for orthopedic practice and for accident surgery. Intramuscular injection of oxygen-ozone mixture is mainly applied in some cases with obstinate carcinoma patients or as a supportive therapy together with the so-called "minor" autohemotherapy. This is a successful therapy: painless, harmless and widely applied in inflammatory processes. "Major" and "minor" autohemotherapy have been applied since 1968 in cases of arthritis, hepatitis, allergies and herpes.

\subsection{Ozone-Olive Oil}

This method of external application is harmless and has found a tremendous success in dermatology for treating fistulae, decubitus and ulcer cruries. It is also successfully applied in mycosis and fungus finger and fingernail infections. Simply, patients has to put their fingers into a plastic sleeve covered by ozone-olive oil. Salzer et al. [33] have investigated the effect of ozonides olive oil on patients suffering from soorkolpitis. An especially positive effect was observed in its application in the vagina. The number of examined bacteria decreased very rapidly. These authors suggest that the positive effect of treatment is due to the ozonides formed as well as due to tissue enrichment with oxygen. The same authors used autohemotherapy (100 ml blood enriched with oxygenozone; $1 \mathrm{ml}$ contains 33 gammas ozone) in cases of chronic placenta insufficiency in pregnant women (20 patients about thirtieth week). High performance liquid chromatography (HPLC) analysis indicated increased values. This therapy is also useful for weak bleedings during pregnancy.

Werkmeister [34] described a technique, utilizing ozone gas of $80-100 \mu \mathrm{g} / \mathrm{ml}$ concentration, for wound cleansing and disinffection. Such an effect has not been observed during enzyme treatment. The bacterially infected spot is often washed out by ozone-oxygen mixture.

\subsection{Ozone Therapy of Virus Infections}

Dorstewitz [35] employed autohemotherapy to treat hepatitis. 50-100 $\mathrm{ml}$ of blood from the patient are treated with ozone and then reinjected. 20 patients with herpes simplex and herpes zoster were treated in the same way for 5-10 days. A complete healing of skin lesions was observed. In one of the cases of extensive herpes in the trigeminal region with keratitis, healing was achieved within 10 days, although a persistent opacity of the keratic tissue remained. In six cases of herpes simplex, upon double treatment with ozone, a positive effect was observed after $28 \mathrm{~h}$. It is desirable to start therapy at an early stage of illness.

Morever, the so-called Hematological ozone therapy (HOT) has found wide application [36]. This therapy has been employed since 1947. In a special hyperbaric chamber the air is enriched with ozone by means of UV-Cs lamp. It has been suggested that singlet oxygen is formed under these conditions. $60-70 \mathrm{ml}$ of blood from patients are placed in the HOT apparatus and enriched with oxygenozone. Blood thus treated is reinjected intravenously or intramuscularly into the patients. HOT therapy is applied in the following affections: chronic ulcers and gastritis, prophylaxis in recoveries from myocarditis; lipid metabolism disturbances hypercholesterinae; chronic liver trouble and recoveries from infectious hepatitis; prophylaxis in acute hepatitis, donor blood preliminarily treated with ozone-oxygen mixture migraine; chronic nephritis with increased creatine and urea levels; acute artery retinae occlusions; chronic polyarthritis; scab treatment after burning; acute bleeding of the eye. Most likely, HOT therapy enhances prostoglandine synthesis. Following HOT therapy, the cholesterol level of 32 patients was examined (322 determination tests) . It was found that the cholesterol level dropped at an average of $20 \%$ with respect to the initial values. It was also demonstrated that this therapy caused no toxic effect on the marrow by blocking the enzyme system.

\subsection{Circulatory Disturbances}

Major autohemotherapy is applied if the artery in question is not accessible to palpation. However , in cases of milder circulatory disturbances, intramuscular and/or subcutaneous injections may be sufficient. Rokitansky [37] widely recommended an external ozone gas therapy in the advanced stages of gangrene which prevents from further inflammation. He has indicated that as a result of intravascular therapy applied in gangrene of the toes of the foot, the average rate of amputations at the upper thigh is reduced from $15 \%$ to $8 \%$ in stage III. In some cases during the postoperational period, an extensive formation of necrosis with purulent secretion might start to develop. However, by making use of intraarterial ozone injection and local ozone-oxygen gas treatment, it became possible to improve circulation and oxygenation of the tissue. Ozone 
therapy was also applied to treat gas gangrene. Guineapigs were treated every day with $450 \mu \mathrm{g}$ of ozone. The death-rate decreased from $97 \%$ to $72 \%$ [38].

\subsection{Ozone Therapeutic Doses}

Peripheral artery circulatory disturbances are treated with intraarterial ozone injections at a maximum concentration of $33 \mu \mathrm{g} / \mathrm{l}$. In autohemotherapy the concentration should not exceed $40 \mu \mathrm{g} / \mathrm{l}$ because of risks to develop hemolysis [39].

\subsection{Ozone Effect on Immunoglobulins}

Immunoglobulins are proteins produced from lymphoid cells, which are unified according to similar general principles of their structural organization. The functional integrity of various classes of immunoglobulins is reduced to their participation in homeostasis, the most important factor of immunological defense systems. Immunological processes are associated with the presence of antibodies. Five classes of immunoglobulins are known: IgG, IgA, IgM, IgD, and IgE. Changes of normal levels cause certain troubles, e.g., increased levels of IgG lead to chronic liver diseases. Washuttl and Viebahn [40] have studied the effect of ozone on the immune system by monitoring changes of immunoglobulins levels in blood.

Nineteen patients with cervix carcinoma and 20 patients with ovarial carcinoma were included. They were injected intravenously with ozone-oxygen mixture (540 $\mu \mathrm{g}$ of ozone, 5 days). 34 patients with chronic rheumatic troubles underwent autohemotherapy through intramuscular injections with $5 \mathrm{ml}$ of blood from patients enriched with $300-350 \mu \mathrm{g}$ of ozone.

$1000 \mu \mathrm{g}$ of ozone were administered intravenously into 47 patients every week for 6 months (50-60 ml of blood from patients enriched with ozone). Statistical data processing indicated insignificant changes of $\operatorname{IgA}$, IgG and IgM levels. Therefore, no immunodeficient effects were observed. Certain changes of IgG levels can be evaluated as immunostimulating.

\subsection{Ozone Influence on Tumor Tissue (in vitro)}

The inhibiting effect of ozone on tumor tissue has been investigated by Sweet [41] and confirmed this effect, his attention being attracted to the effect of ozone on tumor metabolism.

Steinerl et al. [42] studied changes in the levels of DPG, DPN, F-6-PK, GAPDH, HBDH, ICDH, LDH, and NAD in carcinomatous and healthy ovarial tissues (in vitro) under the influence of ozone. Cytostatics like Adriblastin and Xoloxan were also used for reference purposes. The lysolecithin levels decreased in the tumor tissue but did not change in the healthy one, which indicates that ozone has no influence on tumor metabolism. However, the ozone therapy has a positive effect in employing ozone in tumor tissue.

\subsection{H aematological Effect}

Brinkman and Lamberts [43] were the first who reported about the effect of ozone on erythrocyte behaviour. These authors exposed volunteer patients to the influence of ozone (1 ppm) for $10 \mathrm{~min}$ and then measured the oxygen evolved from hemoglobin. Upon prolonged ozone exposures oxygen is not bound with hemoglobin which causes blood-vessel occlusions in fingers and toes. Chow and Mustafa [44] have observed changes in red blood cell biochemistry, the RBCs being taken from mice and apes. Brickley et al. [45] have investigated the morphological and biochemical changes in human red blood cells for ozone concentration of $0.5 \mathrm{ppm}$. This study indicated a $20 \%$ increase of erythrocyte shortness, a $20 \%$ drop in acethylcholine esterase activity, a $15 \%$ fall in glutathione levels (GSH) and a comparatively slight increase in the activity of lactic dehydrogenase (LDH). Some authors [46-48] have suggested that due to inhaled ozone the amount of oxygen free radicals increases. As a result of this, hydrogen peroxide, which might be a notable oxidative metabolite, also increases its levels. The catalase activity in the red blood cells is diminished by $50 \%$ and the intracellular hydrogen peroxide is formed upon ozone exposure of 5-6 ppm.

Lamberts and Veninga [49] have observed changes in erythrocyte membranes stability. Ozone concentrations of $0.25 \mathrm{ppm}$ from 1 to $6 \mathrm{~h}$ change the erythrocyte spherical shape which may change the normal capillary permeability. Schulz et al. [50] have found that exposures of $0.7 \mathrm{ppm}$ ozone for $2 \mathrm{~h}$ increase the methemoglobin levels and decrease the total number of red blood cells. In some mice and guinea-pigs the hemoglobin and hematocrit levels increase at high concentrations of ozone as a compensating response against the decreasing number of erythrocytes.

Many authors have investigated the ability of vitamin E to protect erythrocytes and lung tissue from the influence of ozone because, being a biological antioxidant, ozone interferes with the metabolism and protects other vitamins, hormones and enzymes from oxidation [51-53]. Chow and Kaneo [53] found that under vitamin E deficiency in mice food during a 7 day period with 0.8 ppm ozone, the activity of glutathione peroxidase, pyruvate kinase and LDH in the erythrocytes was enhanced while the total glutathione level was decreased. A low redox potential of the cell constituents is maintained which preserves the thiol groups of a number of enzymatic proteins in a reduced state, the principal function of glutathione being elimination of hydrogen peroxide formed during direct oxidation of 
certain drugs. The toxic effect of hydrogen peroxide is due to its ability to oxidize hemoglobin to methemoglobin and to form hydroperoxides with unsaturated fatty acids which leads to changes in the lipids of cell membranes.

The effect of ozone on erythrocyte membranes has been investigated with respect to the SH groups in some enzymes. At an ozone concentration of $40 \mathrm{nmol} / \mathrm{min}$ over $5 \mathrm{ml}$ membrane suspension, the activity of ATPase is totally lost. The latter can be regenerated by means of phosphatidilserine [54]. Peterson [55] observed changes in T-lymphocyte and B-lymphocyte levels for an ozone concentration of $784 \mu \mathrm{g} / \mathrm{m}^{3}$ for $4 \mathrm{~h}$.

\subsection{Changes in the Serum}

Canada and Airriess [56] studied changes in the concentration of vitamin $\mathrm{E}$, vitamin $\mathrm{A}$ and vitamin $\mathrm{C}$ (antioxidants) in the human serum after exposure to ozone concentration of $0.37 \mathrm{ppm}$ for $2 \mathrm{~h}$. These changes were insignificant. The alkali phosphatase in the serum increased at ozone concentrations of $10 \mathrm{ppm}$ for $1 \mathrm{~h}$. This was explained by the fact that blood tissues let the enzymes pass because of a visible danger to lungs at these concentrations. Murphy and Davis [57] as well as Giri and Hollinger [58] have followed the concentration levels of prostoglandines PGFa and PGEa during exposure of mice to ozone at concentrations of $4 \mathrm{ppm}$ for $8 \mathrm{~h}$. They observed an increase by 186 and $200 \%$ respectively, which was attributed to arachidonate oxidative induction by plasma membranes. Veninga and Wagenaar [59] established that creatine kinase (CPK) levels increased after exposure to $0.02 \mathrm{ppm}$ ozone for $2 \mathrm{~h}$ but unexpectedly there were no changes at higher ozone concentrations. Probably, this fact is associated with some adaptation of the organism.

There was response in serum lipids [60] at $1.1 \mathrm{ppm}$ ozone for $24 \mathrm{~h}$ : the activity of lecithincholesterol transferase, free cholesterol, and lipoproteins increased, however, there was a descending tendency in triglyceride levels. The bacterial effect of ozonized blood serum on gram of negative bacteria (Klebsiella, Pseudomonas and Sallmonela) has also been studied. This effect is dependent on the serum ozonation time, type of bacteria and bacterial membrane structure [61]. Prolonged exposures to ozone (from 0.4 to $1 \mathrm{ppm}, 6 \mathrm{~h}$ daily) caused a drop in serum albumen levels and increased the $\alpha$ - and $\beta$-globulin levels. The total protein level did not change [62].

\subsection{Bactericidal and Virucidal Mechanisms}

In cases when the microorganisms come into direct contact with ozone in a sufficient quantity, killing off the microbes most certainly takes place via the oxidative decomposition of the capsid/protein shell of the virus, thus exposing their DNA and RNA components to the open attack: the presence of DNA and A catabolism products could be demonstrated empirically [48].
In the treatment of virally produced diseases such as herpes or hepatitis, however, the circumstances are quite different. In this case, a completely different method of application must be applied, which is safer for a patient, the choice here generally being in favour of "major autochaemotherapy", whereby the patients own blood receives an admixture of ozone upon withdrawal from a body and is immediately put back into the system whereas during ozone gas therapy session lasting for $5 \mathrm{~min}$ a wound receives almost $800 \mathrm{mg}$ of ozone, as acute case of virus infection needs only $10 \mathrm{mg}(10000 \mu \mathrm{g})$ of ozone in autohaemotherapy.

It is for this reason that as an active mechanism of killing off the virus does not come into question, such as in the case for wound treatement: instead, there are two processes to be discussed here which probably take place simultaneously: i) virus inactivation through ozone or ozone peroxides; ii) a peroxide intolerance of those body cells infected by viruses. Therefore, this means that in ozone/ oxygen therapy, not only the reactions of ozone itself, but also those of its reaction products must come under discussion. In spite of the large number of organic substances in blood, the reaction processes involving ozone are limited to a number of individual parameters, as unsaturated fatty acids constitute the reaction partners of ozone by preference, these being available in excess. The first step can be seen in the familiar 1,3-dipolar cycloaddition. The short peroxide chains should be viewed primarily as the decisive reaction products, reactivity of which is still great enough to avoid their quantitative presence.

The intervention of ozone and/or its peroxides ought to take place at the acceptors of the free virion, whereas the virus-to-cell contact and thus the entire reproductive cycle is interrupted. The authors show the model of a virus with the acceptors which react chemically in the form of $\mathrm{N}$-acetylglucosamine with the corresponding receiver substance of the cell ( $N$-acetylneuraminic acid) producing condensation, thus enabling the virus to penetrate the host cell.

The free pair of electrons on the nitrogen of the $\mathrm{N}$ acetylglucosamine probably represents the point of attack for the electrophilic ozone molecule or its peroxides, so that the virus is blocked for a further reaction by oxidation, making it effectively inactive. Apart from this, the ozone electrophilic reaction can also take place with unsaturated fatty acids, as a membrane constituent of the virally infected body cell, and injects peroxides into the cell. The infected cell, however, already produces hydrogen peroxide as a defensive function, so that further peroxides are no longer tolerated and the cell burst before reproduction of viruses has been completed, or that new peroxides thus introduced produce a synergistic effect, destroying the microorganisms which have penetrated the cell. Chronic infections are bound to occur just at the very point when 
leucocytes are no longer capable of killing bacteria, i.e., when no hydrogen peroxide or neglect quantity of it is formed.

It is at this point that the positive influence of the peroxides formed during ozone treatment at once becomes understandable.

Intravascular ozone/oxygen injection using small quantities of ozone constitutes a direct intervention in the metabolic process, particularly in that of the erythrocytes, as these form a majority by number. The first step of the reaction can be seen in the electrophilic addition of ozone to the double bonds of the unsaturated fatty acids in the phospholipid layer of the erythrocyte membrane, as already described above. This means that short-chain peroxides enter the erythrocytes and influence their metabolism in a characteristic manner. This functional sequence evolves in a way similar to that of an oxygen stress situation. The one aspect peculiar to the normal erythrocyte metabolism is to be found in the direct glucose oxidation in the form of the normal glycolysis and in the metabolic transformation of glucose via the pentose phosphate cycle, which final product, fructose-6-phosphate or glycerinealdehyde-3-phosphate is reintroduced in the normal passage of glycolysis under formation of 1,3-diphosphoglycerate. In the secondary process, 2,3-diphosphoglycerate is formed, which is of decisive importance for deoxygenation of hemoglobin. Under the effect of peroxides, the detoxifying mechanism of these substances is immediately put into action via the glutathione system. Here, as in the case of membrane lesion, it also becomes clear that the solute quantities of ozone in oxygen/ozone therapy have to be selected at allowable level. In order to maintain the glutathione redox system, the pentose/phosphate path must be accelerated in order to cover the ADPH debit as a reducer for GSSG. This means, simultaneously, an increased breaking down of sugar. The decisive product of the accelerated glucose metabolism is the presence of the 2,3-DPG (diphosphoglycerate), now occurring in the lateral path (as an additional) in more abundant quantities, which represents, as a deoxygenated substance, a key compound in the curative effect of ozone.

$$
\mathrm{HbO}_{2}+2,3 \mathrm{DPG}=\mathrm{Hb}^{\bullet} 2,3 \mathrm{DPG}+\mathrm{O}_{2}
$$

Every increase in 2,3-DPG levels facilitates the release of oxygen through shifting of the $\mathrm{HbO} / \mathrm{Hb}$ balance in favor of deoxygenated hemoglobin. As hemoglobin is very stable, particularly in the case of diabetics, ozone therapy is particularly indicated for this disease and brings about an improvement in the peripheral oxygen supply. It is possible, by measurement of arterial and venous partial pressures of $\mathrm{pO}_{2}$, to observe in vivo the change in the oxygen situation during the course of treatment.
However, not only the increase in arterial $\mathrm{pO}_{2}$, but primarily the reduction in venous $\mathrm{pO}_{2}$ is decisive for an increased supply of oxygen, which is equal to an increase in the arterial/venous $\mathrm{pO}_{2}$ difference, even up to normal values of $\mathrm{pO}_{2}=60 \mathrm{~mm} \mathrm{Hg}$.

\subsection{Ozone Neurological Effects}

Many authors have worked on this problem [63]. There is a proper influence of ozone on the central nervous system. Exposures to $>0.6$ ppm ozone concentrations cause a headache and lethargic states. Changes in the visual sharpness (0.3 ppm) and eye muscle may occur [64]. Trams and Lauter [65] have observed a fall in the cerebral levels of catechol-o-methyl transferase on exposure of dogs to $1 \mathrm{ppm}$ of ozone $(8,12$ or $18 \mathrm{~h}$ ). The reduction of enzyme activity was in good correlation with a decrease in catechol amounts in the brain (mosaic).

Ozone exposures (0.5 ppm, $140 \mathrm{~min}$ ) did not affect the cerebral cortex but increased the intraeye pressure (ophthalmic pressure) [66]. Visible effects with sensitive patients were found for ozone exposures of $0.2 \mathrm{ppm}$ [67].

\subsection{Effects on the Liver}

Takanashi and Miura [68] have reported a considerable fall in the activity of metabolite enzymes in the liver: benzopyrene hydroxylase, 7-ethoxycumarine- $O$ diethylase and aniline hydroxylase. No effects were observed on $p$-nitroanisole- $N$-dimethylase activity on exposures to ozone of $0.8 \mathrm{ppm}$ for $7 \mathrm{~h}$. A $20 \%$ drop in cytochrome $\mathrm{P}-450$, NADPH cytochrome, P-450 reductase and cytochrome B5, included in mitochondria and/or ergastoplasma membranes, was established. Fluorescent pigments in the liver being an end product in lipid oxidation, increase upon exposure to $1.5 \mathrm{ppm}$ ozone for 30-60 min.

\subsection{M utageneous Effect}

Zelac and Cromroy [69] have established that ozone is a better mutant than radiation. Persons exposed to $0.5 \mathrm{ppm}$ ozone from 8 to $10 \mathrm{~h}$ manifested chromatid and chromosomal aberrations. No increase in chromosomal aberration was observed at $0.4 \mathrm{ppm}$ ozone for $4 \mathrm{~h}$.

\subsection{Influence on the Cardiovascular System}

In tracheotomy with dogs, which acquired interrupted respiration accompanied by hypertension and bradicardia during exposure to ozone (50 ppm, $4 \mathrm{~min}$ ), the symptoms decreased due to stimulated parasympathetic vagus nerves [70,71]. Exposure of rabbits to ozone $(0.2 \mathrm{ppm}, 5 \mathrm{~h})$ gave rise to pathological changes without myocardial damage but cell membranes did not remain intact. 


\subsection{Influence on the Endocrine System}

Ozone causes a multiplex effect on the endocrine system [72]. The authors report an inhibiting effect on ${ }^{131}$ I (ozone 4 ppm, 5 h) which was observed even 12 days after exposure. Plasma thyrotrpopin was reduced by $50 \%$. The thyroid gland increases its size. The authors suggest that the decreased thyroid hormone levels appear to be prophylactic against ozone damage.

\subsection{Other Effects}

Gordon et al. [73] have reported that upon inhalation of ozone $(0.8 \mathrm{ppm}, 1 \mathrm{~h})$ the activity of choline esterase was diminished not only in blood, but also in the diaphragms of guinea-pigs by $14 \%$ and lung tissue $(16 \%)$. Eskerv and Scheuchenzuber [74] investigated the influence of ozone on the immune system. Exposures of $0.6 \mathrm{ppm}$ for $2 \mathrm{~h}$ did not affect the number of T-lymphocytes. However, an exaggerated spleen was observed during ozone exposure of $0.31 \mathrm{ppm}$ for $103 \mathrm{~h}$. Kidneys manifested dilated tubules.

\section{Toxic Action}

\subsection{Mechanism of Ozone Toxic Operation}

Mechanisms according to which ozone damages biological tissue are not clearly defined. However, several processes should be considered which lead to disturbances in normal cell functioning. Ozone oxidizes polyunsaturated fatty acids (PUFA) in the cell membranes according to Criege's mechanism [75]. Also, it contributes to the increase of malonic dialdehyde content and interacts with natural antioxidants (vitamin C, vitamin A and vitamin E). On the other hand, ozone reacts directly with aminoacids in tissues, proteins, and small peptides [60]. It inactivates the following enzymes: lysozymes, betaglucoronidase and acid phosphatase, while urease is resistant to ozone. Very likely, the cellular regulation of the electrolytes becomes worse and in consequence of this, the enzymes become inactivated and the mitochondrial metabolism is changed. Normal cell functioning is disturbed which might lead to a cell destruction [76].

\subsection{Experimental Evaluation of Ozone Toxicity}

Lung tissue, being vulnerable to ozone attack, has been the object of many investigations. Biochemical studies indicated changes of enzyme levels, the enzymes being an integral part of the intracellular protection from disturbances. These enzymes bind with free radicals, lipid peroxides, and hydrogen peroxide which are factors for changes of tissue. Chow and Hussain [77] have reported about the enhanced activity of glutathione peroxidase in mice inhaled with 0.8 ppm ozone for 3 days. Other natural antioxidants, such as superoxide dismutase, catalase, vitamin $\mathrm{E}$, and vitamin $\mathrm{C}$, destroy free radicals, thus contributing to reduce the risk of permanent tissue damage due to ozone. For example, bronchia constriction, caused by ozone, fades away or disappears after treatment with vitamin $\mathrm{C}$ or with combination between vitamin $\mathrm{E}$ and vitamin $C$ (synergistic effect). This is explained by their antioxidant effect. Complementary biochemical investigations of ozone toxicity involve measurements of the enhanced synthesis of collagen which induces fibrosal changes in lung tissue [78, 79].

\subsection{Influence of Small Ozone Doses on the Enzyme System}

Exposure of mice to small doses of ozone [80] gave rise to changes in two enzyme systems: i) a decrease in the hepatic ascorbic acid (RAA) concentration; ii) a change in the creatine phosphokinase (CPK), RAA was considerably changed for 30 and 120 min after cessation of the ozone exposure whereas CPK demonstrated changes only $15 \mathrm{~min}$ after that. Compared to reference animals, no significant changes were observed after $24 \mathrm{~h}$ for RAA and $30 \mathrm{~min}$ for CPK. Plasma histamine lactodehydrogenase was not affected with various doses of ozone. It is assumed that this is due to the ability of organisms to adapt themselves to the harmful agent which, on the other hand, stimulates metabolite processes and enzyme activity. At higher doses of ozone the enzyme activity gradually falls down, probably due to some compensatory balanced condition. At ozone concentrations of $0.8 \mathrm{ppm}(8 \mathrm{~h})$ the activity of the total lactate dehydrogenase (LDH) in the lungs was enhanced but not in the plasma and erythrocytes. The LDH-5 fractions from LDH isoenzymes considerably decreased in terms of their distribution in the lungs and plasma, while the fraction LDH-4 increased. No change of isoenzyme activity in the lungs, plasma and erythrocytes was observed for ozone concentration of $0.5 \mathrm{ppm}$ [81].

Saymor [82] has studied the behaviour of mice upon prolonged exposure (120 days) to small doses of ozone.The DNA and RNA levels in the lungs decreased whereas the protein level increased.

In vivo and in vitro high ozone concentrations are prerequisite for suppressed mitochondrial oxygen consumption and oxidative phosphorization and for increased membrane permeability. This can be associated with thiol groups oxidation and lipid oxidation [83]. 


\subsection{Ozone Disinfecting Properties}

Ozone exhibits a $100 \%$ bacteriological effect at concentrations of $0.023 \mathrm{mg} / \mathrm{l}$ without producing spores. Spores are destroyed at $0.61 \mathrm{mg} / \mathrm{l}$ [67]. At the same concentration $87.5 \%$ of the hepatic virus B is inactivated. Large amounts of blood can be conserved without clotting by bubbling with an oxygen-ozone mixture. Parallel to this, all the microbial materials in blood are oxidized, thus sterilizing it [84].

\subsection{Influence of Ozone on the Respiratory Tract}

Plopper, Debral, Kelly and Drechsler [85-88] have evaluated the short-term influence of ozone on human health. The transitory effect of ozone on the respiratory function was investigated by measuring the forced vital capacity (FVC), the forced expiratory volume for one second (FEV), the peak flow rate (PFR), and the maximum midexpiratory flow (MMEF).

Miller et al. [89] have made comparative models of ozone operation regions in the respiratory tract. They suggested a new pharmacological model of ozone acute influence on perons and has compared the effect of ozone (ozone $120 \mathrm{ppb}, 2.5 \mathrm{~h}$ ) on children and adults lungs. This author observed a considerable lowering of PFR and FEV values with adults compared to children. He succeeded in measuring the PFR baseline: 3.9 and $2.7 \%$ with adults and children, respectively. Adults made more symptomatic complaints than children. Stock and Kotchmar [90] reported that there is almost no risk of asthmatic attack for patients suffering from asthma at ozone concentrations over $120 \mathrm{ppb}$. Many authors have investigated the influence of ozone on pulmonary lysosomes and mitochondria. Lysosomes contain quite many enzymes, mainly hydrolases, such as protease, lipases, nucleases, phosphatases, phosphodiesterases, etc. Dillar et al. [91] have studied the changes in lysosome levels upon exposure of mice to ozone $(0.7 \mathrm{ppm})$. The activity of pulmonary lysosomal cathepsin $\mathrm{A}$, cathespin $\mathrm{D}$, acidic phosphatase, $\beta$ - $N$-acetylglucose aminidase and benzyl arginine $\beta$-naphtylamide amidohydrolase increased. This is due to inflammatory processes caused by ozone. The specific activity of proteas and peptidase in the lungs enhanced when related to chronic obstructive genetic lack of $\alpha$-1-antitrypsin factor.

Mitochondria are contained in every cell. A highly organized and specialized transportation chain, which transfers protons and electrons to molecular oxygen, is located in the internal mitochondrial membrane. It is composed of enzymes, redox systems which organize proteins and lipids and is called a respiratory chain. The external membrane contains enzymes from the tricarboxylic acid cycle, fatty acid $\beta$-oxidation, etc. Mohammed and Anthony [92] have established that ozone
(2 ppm) decreases oxygen consumption of pulmonary mitochondria in rodents whereas this consumption increases at $0.8 \mathrm{ppm}$ ozone after inhalation for 20 days. Mice, exposed to 0.8 ppm ozone, obtained an acute ozone intoxication due to blocking of the alveolar capillary function, followed by hemolysis and lethal hypoxia. Paister, Godstein and Elaine [93-95] have studied in detail the cellular, biochemical, and functional effects of ozone on the lungs.

\subsection{Clearance Effect}

Clearance of foreign materials (particles) from the lungs and airways depends on the function of macrophages, ciliated cells and secretory cells, and on the physical and chemical properties of the alveolar cells. All these are affected by the ozone exposure. Single acute exposures of animals and people to ozone concentrations less than $0.6 \mathrm{ppm}$ have been shown to accelerate clearance of particles from the tracheobronchial tree whereas acute exposures to ozone levels greater than $0.6 \mathrm{ppm}$ caused a delay in a particle clearance [79]. Repeated exposures ( $2 \mathrm{~h}$ daily for 14 days) to $0.1 \mathrm{ppm}$ ozone gave rise to acceleration in alveolar clearance of latex particles but had no effect on the tracheobronchial clearance. These results, related to morphologic studies, are consistent with certain adaptation [96-101].

\subsection{Alveolar M acrophage Effecf}

The alveolar macrophage (AM) takes part in defending the alveoli and airways against inhaled particles and pathogens. To carry out this important function, AM maintains active mobility, phagocytic activity, membrane integrity and enzymatic capacity. Ozone exposure of AM in vivo has been shown to alter the number and morphology of AM, depending on dose and duration of exposure. A transient decrease in the absolute number of AM has been observed following exposures to high ozone concentrations [102, 103]. AM recovered in rats exposed for $16 \mathrm{~h}$ to $0.05,0.10,0.20$ or $0.40 \mathrm{ppm}$ ozone showed no differences in a cell yield or cell viability. An increase in AM numbers has also been observed after in vivo ozone exposure [104]. Recruitment and persistence of AM results from chemotaxis and migration of cells into the lung alveoli and from local proliferation. A primary function of AM is the maintenance of sterility in the lungs by phagocytosis of foreign particles. Changes in the phagocytic activity of AM have been observed following exposure to ozone. A marked depression of this activity was observed after exposure to $1.2 \mathrm{ppm}$ ozone for $5 \mathrm{~h}$ [105] but enhanced phagocytic function has been observed after prolonged exposures for 20 days ( 3 times daily) to $0.8 \mathrm{ppm}$ ozone. This difference in the phagocytic function of AM for various ozone concentrations and exposure conditions can be explained by changes in the cell population. Ozone 
exposures also affect the secretory activity of AM and their ability to release factors which stimulate the migration of neutrophils and other cell types into the lungs. A culture monolayer of rabbit AM was exposed for 2 and $6 \mathrm{~h}$ to $0.1,0.3$ or $1.2 \mathrm{ppm}$ ozone. Exposure to $0.3 \mathrm{ppm}$ ozone increases monocyte chemotaxis [106]. Biochemical functions of alveolar macrophage can also be affected. Ozone exposure caused a reduction in intracellular concentrations of acid phosphatase and $\beta$-glucoronidase as well as in lysosomal enzymes [107, 108].

\subsection{Lymphocyte Response}

Exposure of the upper airways of mice to ozone at 0.5-0.8 ppm for 1-24 days has indicated a twofold increase in $\operatorname{Ig} \mathrm{A}^{+} \mathrm{B}-$-lymphocytes. In the deep lungs, exposure to $0.7 \mathrm{ppm}$ ozone for 14 days causes an accumulation of T-lymphocytes $[109,110]$. The number of leucocyte cells in control experiments, $3.8 \cdot 10^{3}$, increased to $7.5 \cdot 10^{3}$ cells in exposed mice. Ozone exposure of lymph nodes of euthymic mice and athymic mice indicated that the histopathologic changes were more extensive in the athymic animals [111].

\subsection{Effect of Ozone on the Immune System}

Changes in immune function depend on the organ, dose and duration of ozone exposure. Concanavalin $\mathrm{A}$ (Con A) stimulates the cell-mediated arm of the immune system. Con A reactivity was unaffected after 4 or 7 days of $0.7 \mathrm{ppm}$ ozone exposure $(20 \mathrm{~h} /$ day $)$ but increased in 1.5 and 3 times after 14 and 28 days, respectively. In contrast, splenic cells of mice manifested decreased reactivity to T-cell mitogens in vitro (phytohemagglutinin, PHA $38 \%$ decrease; Con A $75 \%$ decrease) but not to a B-cell mitogen (lipopolysaccharide, LPS) or to alloantigens [112].

For rats, 7 days of exposure to $1 \mathrm{ppm}$ ozone enhanced the reactivity of splenic cells to PHA, Con A and LPS [113]. Ozone inhalation also gives rise to nonspecific changes. Exposure to ozone at concentrations of 0.4 to $0.8 \mathrm{ppm}$ can induce weight losses and/or thymic and splenic atrophy. A similar effect is observed if steroids are injected into mice, i.e. ozone can produce steroidmediated effects on lymphocytes.

The immune response of the human organism to a foreign agent involves the following cell quartet: macrophage, B lymphocytes, $\mathrm{T}$ helper, and $\mathrm{T}$ suppresser. Amoruso [114] has determined the anion peroxide radical, produced by alveolar macrophage from mice exposed to ozone levels of 3.2 to $10.5 \mathrm{ppm}$. They found decreasing concentration levels. The authors proposed that this decrease in anion peroxide radical amount cannot be due to a direct effect of ozone on cell viability but rather to an infection caused by ozone, i.e. the immune system of experimentally tested animals enhances its activity. Alveolar macrophage of test animals, if stimulated by phorbal myristat acetate (PMA), also decreased the concentration of anion peroxide radical.

\subsection{Adaptation}

Lung lesions observed after one week of exposure to $0.2,0.5,0.8 \mathrm{ppm}$ ozone were more expressed than those observed after 3 months of continuous exposure. Nikula and Thankersley $[115,116]$ suggested that the enzyme levels in the lungs increase which may account for the development of adaptation and tolerance to ozone.

\subsection{Influence of Ozone on Terminal Airways}

Epithelial cells type I and squamous cells appear to be the most sensitive to ozone [117]. An exposure to $0.5 \mathrm{ppm}$ ozone increases the volume but reduces the area of the epithelial cells type I [118]. These cells are regenerated to the normal condition after a week in fresh air and develop certain tolerance to ozone reexposure $[119,120]$. The authors have studied tracheal cells (volume, density) by an electron microscopy. They found that all changes due to chronic ozone exposure were reversible, and normal values being regained, if test animals are exposed to fresh air.

\subsection{Fibroses}

Pulmonary fibroses defined as abnormal accumulation of collagen are developed after prolonged exposures to ozone levels greater than $0.5 \mathrm{ppm}[121,122]$. Chronic ozone effects at concentrations close to that in atmospheric air are hardly noticeable and cannot be measured. Fukase and Hashimoto [123] have exposed mice to $1 \mathrm{ppm}$ ozone for 40 days and found increased levels of total lung collagen but this effect rapidly faded away after 10 days of exposure to fresh air. Chronic exposure to $0.06 \mathrm{ppm}$ ozone ( $13 \mathrm{~h} / \mathrm{day}, 5$ days weekly, 18 months) caused changes in the lung function including a decrease in the general respiratory effect.

\subsection{Application of Ozone as the Sterilizing Agent in the Pharmaceutical Industry and Food Processing Industry}

A method has been developed, according to which ozone is utilized for sterilizing bottles, cans, containers, and glass vessels that find wide application in the pharmaceutical industry and cosmetics [124-126].

Usually sterilization is performed at sufficiently high temperatures which may cause damage of some materials used in the food processing industry, pharmaceutical industry and cosmetics. The effect of ozone on bacteria is well known, especially its toxicity and reactivity 
characteristics, that is why attention should be given to dosage and exposure time. There are patents which describe the application of ozone as the sterilizing agent in the pharmaceutical industry [127]. Physiological solution $(0.9 \% \mathrm{NaCl}, \mathrm{pH}=7)$ is treated with oxygen-ozone mixture containing $15 \%$ ozone for $15 \mathrm{~min}$. The solution is allocated to glass or polyethylene banks which are sealed up. Analysis showed that after $2 \mathrm{~h}$ the microbe number was 0 and after $6 \mathrm{~h}$ the ozone was completely destroyed. Sterilization for $2 \mathrm{~h}$ with $0.5 \mathrm{ppm}$ ozone caused a $100 \%$ lost of legionella pneumoniae [96].

An apparatus has been designed to produce oxygenozone mixtures for sterilization of milk, dairy products, wines, butter and liquid medicines. The experimental setup is described in detail in the patent [97]. The quality of wine, beer and liquor is improved after exposure to ozone.

Ozone levels of $0.01 \mathrm{ppm}$ and rates of $1 \mathrm{l} / \mathrm{min}$ are employed in the pharmaceutical industry and food processing industry. Ozone has been employed for cleaning dialyzers [128] and contact lens [129].

\subsection{Ozonides in Cosmetics}

Ozonides [130] are prepared by means of the reaction between ozone and unsaturated compounds. They do not cause inflammatory processes in skin and are not decomposed by catalase. Ozonides participate as the oxidizing agent without liberating peroxide groups which might oxidize cells. About 1000 subcutaneous injections of castor-oil ozonides have been made without tissue response. A 4\% solution of the sorbic acid ozonide in ethyl diglycol (ozonide SV) is used in cosmetics to preserve face creams and as disinfectant. The lethal dose is $10 \mathrm{ml} / \mathrm{kg}$. In wheat-germ oil, containing vitamin $\mathrm{E}$, the ozonide keeps unchanged vitamin E levels.

\section{References}

[1] Binz C.: Real Encyclopedi der gesamten Helkunder Bd. 18, S. 189, Berlin und Wien 1898.

[2] Brinkmson S. and Lambert K.: Nature, 1958, 181, 1202.

[3] Shepatlnovskii V. and Mikashinovich Z.: II Vsesousnaya konferencia "Poluchenie I primenenie ozona". Moskwa 1991, 157.

[4] Schmitthaeusler R.: Pat. EP0261032. Publ. March 23, 1988.

[5] Carpendiae M. and Freeberg J.: J. Clin. Gastroenterol., 1993, 17, 142.

[6] Belianin I. and Shmelev E.: Ter. Arkh., 1994, 66, 29.

[7] Sato H.: Exp. Anim., 1990, 39, 223.

[8] Grits N. and Formichev A.: Microbiologiya, 1990, 59, 831.

[9] Heindh L.: Zentralbl. Hyg. Unwelmed., 1993, 194, 464.

[10] Ancowski S.: Complement Inflammation, 1990, 7, 57.

[11] Kontorshtikova K. and Andreeva N.: II Vsesousnaya konferencia “Poluchenie I primenenie ozona". Moskwa 1991, 157.

[12] Aliev M. and Ioffe L.: ibid, 161.

[13] Krivatkin S.: ibid, 156.

[14] Gloor M. and Lipphardt B.: Zh. Hautkr., 1976, 51, 97.

[15] Sweet F.: Science, 1980, 209, 931.
[16] Richter A.: J. Toxicol. Environ. Health, 1988, 25, 383.

[17] Uehara K.: Pat. EP0601891. Publ. June 15, 1994.

[18] Burleson G. and Murray T.: Appl. Microbiol., 1975, 29, 340.

[19] Karzenelson E., Koerner G. And Biederman N.: Appl. Environ. Microbiol., 1979, 37, 715.

[20] Vaughn J. and Chen Y.: Appl. Environ. Microbiol., 1987, $\mathbf{5 3}, 2218$.

[21] Lee R.: Semin. Oncol., 1974, 1, 254.

[22] Rokitansky O.: Hospitalis, 1982, 52, 643.

[23] Storczynski J. and Antoszewski Z.: Pol. Tyd. Lek., 1992, 47, 964.

[24] Turzynski B. and Stroszynski J.: Pol. Tyd. Lek., 1991, 46, 700.

[25] Rilling S.: “Ozone” Sci. Eng. Intern., 1985, 7, 257.

[26] Schulzs S.: Lab. Anim., 1986, 20, 41.

[27] Kramer F.: Erfahrungsheilkunde, 1975, 24, 120.

[28] Kramer F.: Ozonachrichten, 1983, 2, 65.

[29] Turk R.: Erfahrungsheilkunde, 1976, 25, 177.

[30] Pribluda S.: Semana Med., 1963, 123, 10.

[31] Wolff H.: Das medizinische Ozon. vfm Publications, Heilderberg 1979.

[32] Payr E.: Munchner Medizinische Wochenschrift, 1935, 82, 220.

[33] Salzer N., Metka M. and Shonbauer M.: Erhfahrungsheilkunde, 1983, 32, 9731.

[34] Werkmeister H.: Erfahrungsheilkunde, 1976, 25, 180.

[35] Dorstewitz H.: Kongres-bericht der artztlichen geselltschafen fur ozontherapie, Baden-Baden 1981.

[36] Stadlaender S.: Erfahrungsheilkunde, 1981, 30, 277.

[37] Rokitansky O.: Hospitalis, 1982, 52, 711.

[38] Rotter M. and Mittermayer H.: Wien Klin. Wochenschr., $1974, \mathbf{8 6}, 776$.

[39] Washuttl J.: Erfahrungsheilkunde, 1979, 28, 811; 1983, 32, 815 .

[40] Washuttl J., Viebahn R.: “Ozone” Sci. Eng. Intern., 1989, 11, 411.

[41] Sweet F.: Science, 1980, 202, 931.

[42] Viebahn R. and Steiner I.: “Ozone” Sci. Eng. Intern., 1989, 12,65 .

[43] Anbrinkm, R. and Lamberts H.: Nature, 1958, 181, 1202.

[44] Chow C. and Mustafa M.: Environ. Physiol. Biochem., $1975, \mathbf{5}, 142$.

[45] Brickley R., Hackney J. and Clark K.: Arch. Environ. Health, 1975, 30, 40.

[46] Goldstein B.: Arch. Environ. Health, 1975, 26, 279.

[47] Vender R.: Toxicol. Ind. Health, 1994, 10, 53.

[48] Pryor W.: Chem. Biol. Interact., 1991, 79, 41.

[49] Lamberts H. and Veninga T.: Lancet, 1964, 1, 133.

[50] Schulz E., Moore G. and Calabrese E.: Bull. Environ. Contam. Toxicol., 1981, 26, 273.

[51] Chow C. and Tappel A.: Arh. Environ. Health, 1973, 26, 205.

[52] Sato S. and Kawakami M.: Am. Rev. Resp. Dis., 1976, 113, 809.

[53] Chow C. and Kaneko J.: Environ. Res., 1979, 19, 49.

[54] Chan P. and Kindya R.: J. Biol.Chem., 1977, 252, 8537.

[55] Savino A. and Peterson M.: Environ. Res., 1978, 15, 65.

[56] Canada A. and Airriess G.: Nutrit. Res., 1987, 7, 797.

[57] Myrphy S. and Davis H.: Toxicol. Appl. Pharmacol., 1964, 6, 528.

[58] Giri S. and Hollinger M.: Environ. Res., 1980, 21, 467. 
[59] Veninga T. and Wagenaar J.: Environ. Health Perspect., 1981, 39, 153.

[60] Shimasaki H. and Takatori T.: Biochem. Biophys. Res. Comm., 1976, 68, 1256.

[61] Jankovski S. and Doroszkiewicz W.: Complement Inflammation, 1990, 7, 57.

[62] Jegier Z.: J. Am. Ing. Hyg. Assoc., 1974, 137, 329.

[63] Kleinfeld M. and Giel P.: Am. J. Med. Sci., 1956, 231, 638.

[64] Laperwerff J.: Aerospace Med., 1963, 34, 479.

[65] Trams E. and Lauter C.: Arch. Environ. Health., 1972, 24, 153.

[66] Berney W., Dyer R.: US Environ. Prot. Agency OFF Res.

Dev., EPA, 1976, 1, PB-264, 233, 555.

[67] Hackney J.: From Gov. Rep. Announce Index (U.S.), 1977, 77, 98 .

[68] Takanashi Y. and MiuraT.: J. Toxicol. Environ. Health, $1985, \mathbf{1 5}, 855$.

[69] Zelac R. and Cromroy H.: Environ. Res., 1971, 4, 262; 325.

[70] Vaughan T. and Moorman W.: Toxicol. Appl. Pharmacol., 1971, 20, 404.

[71] Uchiyama I.: Environ. Res., 1989, 48, 78.

[72] Fairchild E. and Grahm S.: Toxicol. Appl. Pharmacol., 1964, 6, 607 .

[73] Gordon T., Taylor B. and Amdur M.: Arch. Environ. Health, 1981, 36, 284.

[74] Eskerv M. and Scheuchenzuber M.: Environ. Res., 1976, 40, 274.

[75] Criege R.: Rec. Chem. Prog., 1957, 18, 111.

[76] Menzel D.: Adv. Mod. Environ. Toxicol., 1982, 5, 183.

[77] Chow C. and Hussain M.: Exprl. Path., 1976, 25, 182.

[78] Last J. and Greenberg D.: Toxicol. Appl. Pharm., 1979, 51, 247.

[79] Hussain Z. and Goss C.: Life Sci., 1976, 18, 897.

[80] Veninga T.: Environ. Health Perspect., 1981, 39, 153.

[81] Chow C. and Goss C.: J.Toxicol. Environ. Health, 1977, 3, 877.

[82] Saymor W.: Arch. Environ. Health, 1974, 29, 164.

[83] Mohammad M. and Anthany D.: J. Chest, 1974, 66, 21.

[84] Summer W.: Process Biochem., 1976, 11, 26.

[85] Plopper C.: Toxicol. Appl. Pharmacol., 1994, 121, 124.

[86] Debral L. and Kimberly E.: Environ. Health Perspect. Suppl., 1994, 102, 61.

[87] Kelly F.: Hum.Exp. Toxicol., 1994, 13, 407.

[88] Drechsler P. and Deborah M.: Exp. Geront., 1995, 30, 65.

[89] Miller F., Oventon J. and Kaskot R.: Tox. Appl. Pharm., 1985, 79, 11 .

[90] Stock T. and Kotchmar D.: J. Air Pollut. Contr. Assoc., 1985, 35, 1266.

[91] Dillar C. and Urribarri N.: Arch. Environ. Health, 1972, 25, 426.

[92] Mohammad M. and Anthony D.: J. Lab. Clin. Med., 1973, 82, 357.

[93] Peister A.: Presse Term. Clim., 1977, 1, 58.

[94] Godstein B. and Belchum O.: Toxicol. Appl. Pharmacol., 1974, 27, 330 .

[95] Elaine S. and Dziedzic D.: Toxicol. Lett., 1990, 51, 125.

[96] Schesinger R. and Driscoll K.: J. Toxicol. Environ. Health, 1987, 20, 125.

[97] Abraham W. and Sielezak W.: Eur. J. Respir. Dis., 1986, 68, 114

[98] Foster W., Costa D. and Langenbak E.: J. Appl. Physiol., 1987, 63, 996.

[99] Boorman G., Schwartz L. and Dungworth D.: Lab. Invest., $1980,43,108$.
[100] Nikula K., Wilson D. and Giri S.: Am. J. Pathol., 1988, 131, 373.

[101] Harkema J., Plopper C. and Hyde D.: Am. J. Pathol., 1987, 128, 44.

[102] Kirkpatrik J. and Henderson R.: Exp. Lung. Res. 1989, 15,1 .

[103] Schlesinger R.: J. Toxicol. Environ. Health, 1987, $21,27$.

[104] Lum H. and Plopper D.: Exp. Lung Res., 1983, 5, 61.

[105] Foster M.: J. Appl. Physiol., 1993, 75, 5.

[106] Driscoll K. and Schlesinger R.: Toxicol. Appl. Pharmacol., 1988, 93, 312.

[107] Kimura A. and Goldstein E.: J. Infect. Dic., 1981, 143, 247.

[108] Sherwood R. and Goldstein E.: Environ. Res., 1986, 41, 378.

[109] Bleavins M. and White H.: Toxicologist, 1987, 7, 129.

[110] Bleavins M. and Dziedzic D.: Toxicologist, 1988, 8, 198.

[111] Sell S.: Immunology, immunopathology and immunity. Elsevier, New York 1987.

[112] Aranyi C., Vana S. and Thomas P.: J.Toxicol. Environ. Health, 1983, 12, 55.

[113] Eskew M., Scheuchenzuber W. and Scholz R.: Environ. Res., 1986, 40, 274.

[114] Amoruso M. and With G.: Life Sci., 1981, 28, 2215.

[115] Nikola K., Wilson D., Dungworth D. and Plopper C.: Toxicol. Appl. Pharmacol., 1989, 93, 394.

[116] Tankersley C.: Toxicol. Lett., 1994, 72, 279.

[117] Stephens R., Sloan M. and Reeman G.: Am. J. Pathol., 1973, 74, 31 .

[118] Evans M. and Dekker N.: Exp. Mol. Phatol., 1985, 42, 366. [119] Plopper C., Chow C. and Dunworth D.: Exp. Mol. Pathol., 1978, 29, 400

[120] Nikula K., Wilson D., Dungworth D. and Plopper C.: Am. J. Pathol., 1988, 131, 373.

[121] Hussain M. and Cross C.: Life Sci., 1976, 18, 897; 904.

[122] Last J. and Greenberg D.: Toxicol. Appl. Pharmacol., 1979, 51, 257.

[123] Fukase O. and Hashimoto K.: Nippon Eiseigaku Zassi., 1982, 37, 694

[124] Better A.: Pat. EP 0222309. Publ. May 20, 1987.

[125] Bothner J.: Pat. DE 3.806.203. Publ. September 07, 1989. [126] Faddis C.: Pat. US 5.266.275. Publ. November 30, 1993.

[127] Kuvakina N.: Pat. RU 2.289.812. Publ. December 20, 2006.

[128] Gal G.: Int. J. Artifical Organs, 1992, 15, 461.

[129] Hiromichi M.: Pat. JP 05.329.196. Publ. February 18, 1993. [130] Geabelein K.: Seifen, Oile, Fette, Wasche, 1986, 112, 1718.

\section{ЗАСТОСУВАННЯ ОЗОНУ В МЕДИЩИН}

Анотація. В огляді показано застосування озону в медицині і його вплив на людський організм. Особливу увагу присвячено терапевтичним властивостям, терапевтичним дозам і областям застосування. Приведені деякі механізми впливу озону на різні органи і системи людини. Розглянуто токсичність озону. Показано, щьо озон може застосовуватись як стерилізуючий агент у фармацевтичній, косметичній $i$ харчовій промисловості.

Ключові слова: озон, медицина. 